\title{
Ground-based characterization of aerosol spectral optical properties of haze and Asian dust episodes under Asian continental outflow during winter 2014
}

\author{
Jinsang Jung ${ }^{1}$, JeongAh $\mathbf{Y u}^{2}$, Youngsook Lyu ${ }^{2}$, Minhee Lee ${ }^{2}$, Taekyung Hwang ${ }^{2}$, and Sangil Lee ${ }^{1}$ \\ ${ }^{1}$ Center for Gas Analysis, Korea Research Institute of Standards and Science (KRISS), Daejeon 34113, South Korea \\ ${ }^{2}$ Department of Climate and Air Quality Research, National Institute of Environmental Research, \\ Daejeon 34944, South Korea
}

Correspondence to: Jinsang Jung (jsjung@ kriss.re.kr)

Received: 28 October 2016 - Discussion started: 24 November 2016

Revised: 29 March 2017 - Accepted: 30 March 2017 - Published: 24 April 2017

\begin{abstract}
Long-range transported (LRT) haze can affect the regional radiation budget and the air quality in areas downwind of the Asian continental outflow. Because in situ observations of spectral aerosol optical properties of the LRT haze are rare, an intensive characterization of aerosol optical properties is needed. This study characterized the spectral optical properties of the LRT haze and Asian dust originating from the Asian continent. Integrated chemical and optical measurements of aerosol particles were carried out in a downwind area of the Asian continental outflow (Daejeon, South Korea) during winter 2014. High concentrations of $\mathrm{PM}_{10}$ (particulate matter with a diameter $\leq 10 \mu \mathrm{m}$ ) and light scattering coefficients at $550 \mathrm{~nm}, \sigma_{\mathrm{s}, 550}$, were observed during a long-range transport (LRT) haze episode $\left(\mathrm{PM}_{10}=163.9 \pm 25.0 \mu \mathrm{g} \mathrm{m}^{-3} ; \sigma_{\mathrm{s}, 550}=\right.$ $\left.503.4 \pm 60.5 \mathrm{Mm}^{-1}\right)$ and Asian dust episode $\left(\mathrm{PM}_{10}=\right.$ $\left.211.3 \pm 57.5 \mu \mathrm{g} \mathrm{m}^{-3} ; \sigma_{\mathrm{s}, 550}=560.9 \pm 151 \mathrm{Mm}^{-1}\right)$. During the LRT haze episode, no significant change in the relative contribution of $\mathrm{PM}_{2.5}$ (particulate matter with a diameter $\leq 2.5 \mu \mathrm{m}$ ) chemical components was observed as particles accumulated under stagnant atmospheric conditions (13-17 January 2014), suggesting that the increase in $\mathrm{PM}_{2.5}$ mass concentration was caused mainly by the accumulation of LRT pollutants. On the other hand, a gradual decrease in Ångström exponent $(\AA)$ and a gradual increase in single scattering albedo $(\omega)$ and mass scattering efficiency (MSE) were observed during the stagnant period, possibly due to an increase in particle size. These results imply that a change in particle size rather than chemical composition dur-
\end{abstract}

ing the stagnant period is the dominant factor affecting the aerosol optical properties. During the Asian dust episode, a low $\mathrm{PM}_{2.5} / \mathrm{PM}_{10}$ ratio and $\AA(450 / 700)$ were observed with average values of $0.59 \pm 0.06$ and $1.08 \pm 0.14$, respectively, which were higher than those during the LRT haze episode $(0.75 \pm 0.06$ and $1.39 \pm 0.05$, respectively), indicating that $\mathrm{PM}_{2.5} / \mathrm{PM}_{10}$ mass ratios and $\AA(450 / 700)$ can be used as tracers to distinguish aged LRT haze and Asian dust under the Asian continental outflow.

\section{Introduction}

The optical property of aerosol particles is a very important parameter for understanding the aerosol effects on radiative forcing and climate change. Spatiotemporal distributions of aerosol particles are needed to accurately calculate radiative forcing in the global climate system (Li et al., 2016). Atmospheric chemical transport models (CTMs) are useful tools for estimating the spatial distributions and concentrations of aerosol particles on regional to global scales. In addition to CTMs, satellite remote sensing is widely used to characterize aerosol particles and their impact on climate change and air quality (van Donkelaar et al., 2010). However, both methods are uncertain due to lack of regional specific optical properties. Thus, to improve the accuracy of CTMs and satellite remote sensing, it is essential to validate these approaches using ground-based remote sensing techniques and surface optical measurements. 
With rapid economic growth and urbanization, megacities in China have experienced severe air pollution problems (Chan and Yao, 2008; Liu et al., 2013; Wang et al., 2014). In addition to anthropogenic pollutants, Asian dust originating from major deserts located in northern and western parts of China (e.g., the Gobi desert and Taklimakan desert) influences the air quality of China (Bi et al., 2016; $\mathrm{Li}$ et al., 2016). Asian dust has a high light scattering property (single scattering albedo, $\omega$ at $550 \mathrm{~nm}=0.935$ ) and a low wavelength dependence of optical properties (Ångström exponent, $\AA$ at $440-870 \mathrm{~nm}=\sim 0.2$ ) (Bi et al., 2016), whereas anthropogenic pollutants from megacities in China have relatively high light-absorbing properties ( $\omega$ at $532 \mathrm{~nm}=0.82$ (Guangzhou), 0.86 (Beijing), 0.83 (Shanghai)) and strong wavelength dependence $(\AA$ at 450 $700 \mathrm{~nm}=1.46$ (Guangzhou), 1.42 (Beijing)) (Garland et al., 2008, 2009; Cheng et al., 2015).

Severe haze over China can influence the air quality of downwind areas of the Asian continent and regional environments over east Asia through long-range transport (LRT) by the prevailing westerly (Aikawa et al., 2010; Jung and Kim, 2011; Kaneyasu et al., 2014; Jung et al., 2015). LRT haze can also affect the regional radiation budget directly by scattering or absorbing solar radiation and indirectly by altering the physical properties of clouds and the efficiency of precipitation (Ramanathan et al., 2007; Gao et al., 2014; Jeong et al., 2014; Jung et al., 2015). Zhang et al. (2007) reported that the Asian pollution outflow influences precipitation over the North Pacific. To investigate the impact of LRT haze on regional environments over downwind areas of the Asian continental outflows, it is necessary to characterize the chemical and optical properties of LRT haze.

The $\omega$ is the key parameter used to determine the aerosol effect on radiative forcing and climate change (IPCC, 2013). Thus, accurate measurements of scattering and absorption properties of aerosol particles are important for the better estimation of aerosol radiative forcing. Spectral $\omega$ and the backscattering ratio, defined as the ratio of light scattered in the backward hemisphere to the total light scattered, also provide information for the accurate determination of aerosol radiative forcing (Gopal et al., 2014). However, in situ observations of spectral aerosol optical properties under Asian continental outflows are rare; thus, an intensive characterization of aerosol optical properties is needed.

In Shanghai, China, the $\omega$ measured at the surface shows a weak seasonal variation, whereas a ground-based remote sensing technique shows the highest $\omega$ during the fall season. The $\omega$ measured by ground-based remote sensing $(0.9$ 0.93 ) is $\sim 10 \%$ higher than values measured at the surface (0.8-0.9) (Cheng et al., 2015). From one year's worth of observations in Seoul, South Korea, a trend of increasing $\omega$ with wavelength was observed during Asian dust events, whereas little spectral dependence of $\omega$ was observed during LRT haze events (Jung et al., 2010). During the Campaign of Air Quality Research in Beijing 2006 (CAREBeijing-2006), $\omega$ was found to be closely related to the inflow of air to Beijing. Relatively low $\omega(<0.8)$ was observed for the air mass originating from the north and passing over Beijing, whereas relatively high $\omega$ was observed for the air mass originating from the south of Beijing (Garland et al., 2009). Garland et al. (2009) found that relatively low $\omega$ for the air mass from the north was caused by the high emission of soot from combustion sources in Beijing.

The objective of this study is to characterize the spectral optical properties of the LRT haze and Asian dust originating from the Asian continent during winter 2014. Because fossil fuel consumption increases during winter for space heating and northwesterly winds are dominant during winter, this study focused on winter. Size-segregated mass, chemical, and optical measurements of aerosol particles were carried out at Daejeon, South Korea, during January 2014 to characterize the optical properties of different types of haze. Temporal variations in spectral optical properties under stagnant atmospheric conditions are discussed with reference to aerosol chemical composition. From identified Asian continental outflows, we also investigated the wavelength dependence of aerosol optical properties.

\section{Experimental methods}

\subsection{General description of measurement}

Online measurements of aerosol optical properties and daily $\mathrm{PM}_{2.5}$ (particulate matter with a diameter $\leq 2.5 \mu \mathrm{m}$ ) sampling were conducted at an air quality monitoring station in the megacity of Daejeon, central South Korea $\left(36.19^{\circ} \mathrm{N}\right.$, 127.24 ${ }^{\circ}$ E), during 8-31 January 2014 (Fig. 1). Because Daejeon is located downwind of Asian continental outflows, it is frequently affected by long-range transported pollutants and Asian dust (Jung et al., 2016). Light scattering and absorption coefficients were continuously measured inside a monitoring building ( $\sim 15 \mathrm{~m}$ above the ground) of the National Institute of Environmental Research in South Korea. $\mathrm{PM}_{2.5}$ samples were collected on pre-baked quartz fiber filters (Pall-Life Sciences, $47 \mathrm{~mm}$ diameter) at a flow rate of $16.7 \mathrm{~L} \mathrm{~min}^{-1}$. An aerosol sampler (APM Korea, model PMS-103) was installed on the rooftop of the monitoring building. Before and after sampling, filter samples were stored in a freezer at $-20^{\circ} \mathrm{C}$ and wrapped with aluminum foil. A total of 23 filter samples were collected. Additionally, field blank filters were collected before and after the sampling period. Hourly precipitation data were obtained from a nearby weather monitoring station of the Korea Meteorological Agency.

\subsection{Online measurement of aerosol chemical composition}

$\mathrm{PM}_{10}$ and $\mathrm{PM}_{2.5}$ mass concentrations were measured by a beta-attenuation monitor (Met One Instruments, BAM 1020) with an hourly interval. The detection limit of the 


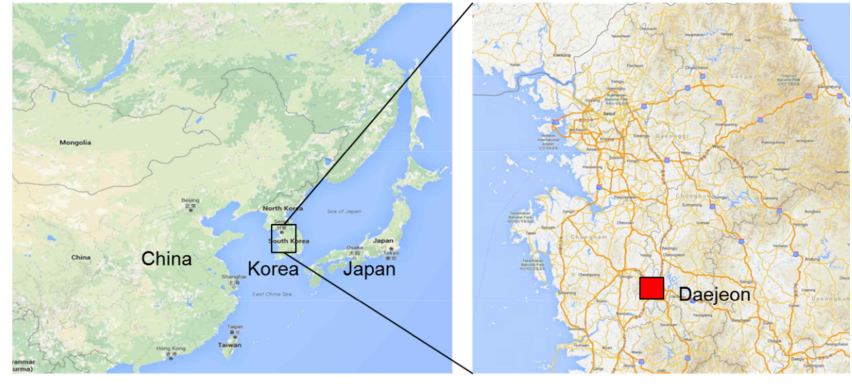

Figure 1. Map of the measurement site $\left(36.19^{\circ} \mathrm{N}, 127.24^{\circ} \mathrm{E}\right)$ in Daejeon, South Korea (base map is from Google Maps).

beta-attenuation technique is reported as $3.6 \mu \mathrm{g} \mathrm{m}^{-3}$ by the manufacturer. Hourly $\mathrm{PM}_{10}$ calcium $(\mathrm{Ca})$ concentrations were continuously measured by X-ray fluorescence (XRF) (Cooper Environmental Service (CES), model Xact 620). The air samples were introduced through a $\mathrm{PM}_{10}$ inlet at a flow rate of $16.7 \mathrm{~L} \mathrm{~min}^{-1}$ and drawn through filter tape. The online Xact 620 monitor was calibrated using thin film standards for each element of interest, which was provided by CES. These standards were manufactured by depositing vapor-phase elements on blank Nuclepore (Micromatter Co.). For a $1 \mathrm{~h}$ time resolution, the minimum detection limit for $\mathrm{Ca}$ has been reported to be $0.32 \mathrm{ng} \mathrm{m}^{-3}$ (Park et al., 2014).

Online measurements of $\mathrm{PM}_{2.5}$ organic carbon (OC) and elemental carbon (EC) were conducted using a semicontinuous carbon analyzer (Sunset Laboratory Inc., model RT3140) based on the thermal-optical transmittance (TOT) protocol for pyrolysis correction and the NIOSH (National Institute for Occupational Safety and Health) 5040 method temperature profile (Birch and Cary, 1996; Jung et al., 2010). Measurement condition of the carbon analyzer was described in detail by Jung et al. (2016). The detection limit of both OC and $\mathrm{EC}$ was $0.5 \mu \mathrm{g} \mathrm{C} \mathrm{m}{ }^{-3}$ for $1 \mathrm{~h}$ time resolution, as reported by the manufacturer. The uncertainty of OC and EC measurements has been reported to be $5 \%$ (Polidori et al., 2006). Hourly averaged mass concentrations of $\mathrm{PM}_{2.5}$, OC, and EC were used in this study.

\subsection{Online measurement of aerosol optical properties}

Light scattering coefficients $\left(\sigma_{\mathrm{s}}\right)$ and hemispheric backscattering coefficients $\left(\sigma_{\mathrm{bs}}\right)$ of aerosol particles at three wavelengths $(\lambda=450,550$, and $700 \mathrm{~nm})$ were continuously measured using an integrating nephelometer (TSI inc., model 3563). The nephelometer was operated at a flow rate of $5 \mathrm{~L} \mathrm{~min}^{-1}$ with a $5 \mathrm{~min}$ averaging time. The clean air and span gas (pure $\mathrm{CO}_{2}$ ) calibrations were carried out every hour and once a month, respectively. The uncertainty of the nephelometer measurements was determined to be less than $2 \%$ with a $5 \mathrm{~min}$ interval. For a $5 \mathrm{~min}$ resolution, the detection limits of $\sigma_{\mathrm{s}}$ were determined to be 6,3 , and $3 \mathrm{Mm}^{-1}$ at 450 ,
550 , and $700 \mathrm{~nm}$, respectively, calculated as $3 \sigma$ of the clean air measurement. Systematic biases caused by angular truncation errors and a non-Lambertian light source were corrected for scattering measurement data using the Ångström exponents of $\sigma_{\mathrm{s}}$ (Anderson et al., 1996; Anderson and Ogren, 1998; Garland et al., 2009). The corrected systematic biases were $\sim 12 \%$ of the measured values. The relative humidity $(\mathrm{RH})$ of the sampled air inside the nephelometer chamber was $21 \pm 10 \%$.

The optical attenuation coefficients $\left(\sigma_{\mathrm{ATN}}\right)$ of aerosol particles were measured using the aethalometer (Magee Scientific, model AE31) at seven wavelengths (370, 470, 520, 590, 660, 880, and $950 \mathrm{~nm}$ ) (Hansen, 2005). Air samples were drawn through the $\mathrm{PM}_{2.5}$ cyclone (BGI Inc., SCC1.829) at a flow rate of $4 \mathrm{~L} \mathrm{~min}-1$. The light absorption coefficient $\left(\sigma_{\mathrm{a}}\right)$ was retrieved from $\sigma_{\mathrm{ATN}}$, as described by Jung et al. (2010), by considering the "shadowing effect" and multiple scattering within the filter. The detection limit of the aethalometer $\sigma_{\mathrm{a}}$, defined as $3 \sigma$ of the dynamic blank, was determined to be $2 \mathrm{Mm}^{-1}$. The measurement uncertainty of the aethalometer is reported to be $\pm 5 \%$ by the manufacturer (Hansen, 2005). Hourly averaged light scattering and absorption coefficients were used in this study.

\subsection{Water-soluble ions analysis of $\mathbf{P M}_{2.5}$ filter samples}

A quarter of each filter sample was extracted with $10 \mathrm{~mL}$ of ultrapure water under ultrasonication (for $30 \mathrm{~min}$ ). Water extracts were then passed through a disk filter (Millipore, Millex-GV, $0.45 \mathrm{~mm}$ ) to remove filter debris and waterinsoluble particles. Water extracts were stored in a refrigerator at $4{ }^{\circ} \mathrm{C}$ prior to analysis. The total organic carbon (TOC) level of the ultrapure water was maintained below $4 \mathrm{ppb}$ using a LabPure S1 filter and an ultraviolet (UV) lamp (ELGA, PureLab Ultra).

Water-soluble inorganic ions were analyzed using an ion chromatograph (Thermo Fisher Scientific, Dionex ICS15000). Analytical conditions of anions $\left(\mathrm{Cl}^{-}, \mathrm{NO}_{3}^{-}, \mathrm{SO}_{4}^{2-}\right)$ and cations $\left(\mathrm{Na}^{+}, \mathrm{NH}_{4}^{+}, \mathrm{K}^{+}, \mathrm{Ca}^{2+}, \mathrm{Mg}^{2+}\right)$ were described in detail by Jung et al. (2016). The detection limits of $\mathrm{Cl}^{-}$, $\mathrm{NO}_{3}^{-}$, and $\mathrm{SO}_{4}^{2-}$, which are defined as 3 times the standard deviation of field blanks, were determined to be $0.02,0.01$, and $0.11 \mu \mathrm{g} \mathrm{m}^{-3}$, respectively. The analytical error of $\mathrm{Cl}^{-}$, $\mathrm{NO}_{3}^{-}$, and $\mathrm{SO}_{4}^{2-}$ measurements was $2.0,1.7$, and $2.3 \%$, respectively. The detection limits of $\mathrm{NH}_{4}^{+}$and $\mathrm{K}^{+}$were determined to be 0.03 and $0.006 \mu \mathrm{g} \mathrm{m}^{-3}$, respectively. The analytical errors of $\mathrm{NH}_{4}^{+}$and $\mathrm{K}^{+}$were determined to be 1.4 and $0.73 \%$, respectively. Daily average water-soluble ions were used in this study.

\subsection{Satellite RGB (red, green, blue) images and air mass backward trajectories}

Moderate Resolution Imaging Spectroradiometer (MODIS) satellite images were obtained from the NASA/MODIS web 
site (https://modis.gsfc.nasa.gov/). Air mass backward trajectories ending at the measurement site were calculated for heights of 200, 500, and $1000 \mathrm{~m}$ above ground level (AGL) using the HYSPLIT (HYbrid Single-Particle Lagrangian Trajectory) model (Draxler and Rolph, 2016; Rolph, 2016). All back trajectories were ended at 00:00 and 12:00 UTC (09:00 and 21:00 LT, respectively) and extended $96 \mathrm{~h}$ backwards.

\subsection{Intensive optical properties}

\subsection{1 Ångström exponent of aerosol light scattering}

The wavelength-dependent aerosol scattering can be expressed by a power law (Ångström, 1929) as follows:

$\sigma_{\mathrm{s}, \lambda}=\sigma_{\mathrm{s}, \lambda \mathrm{r}}\left(\frac{\lambda}{\lambda_{\mathrm{r}}}\right)^{-\AA}$

where $\sigma_{\mathrm{s}, \lambda \mathrm{r}}$ is the scattering coefficient at a reference wavelength $\lambda_{r}$ and $\AA$ is the Ångström exponent. The Ångström exponent can be retrieved from the slope of a doublelogarithmic plot of $\sigma_{\mathrm{s}}$ versus $\lambda$ as follows:

$\AA\left(\frac{\lambda_{1}}{\lambda_{2}}\right)=-\frac{\log \left(\frac{\sigma_{\mathrm{s}, \lambda 1}}{\sigma_{\mathrm{s}, \lambda 2}}\right)}{\log \left(\frac{\lambda_{1}}{\lambda_{2}}\right)}$.

\subsubsection{Backscattering fraction, single scattering albedo, and mass scattering efficiency}

The backscattering coefficient is defined as the scattered light intensity in the backward hemisphere of the particle (90$180^{\circ}$ ) (Anderson and Ogren, 1998). The backscattering ratio is used to derive the slope of the particle size distribution and also provides an estimate of the bulk refractive index of particles in the atmosphere (Gopal et al., 2014). The hemispheric backscattering fraction, $b_{\lambda}$, is defined as the ratio of the backscattering coefficient to the total scattering coefficient at a given wavelength $(\lambda=450,550$, and $700 \mathrm{~nm})$, calculated as

$b_{\lambda}=\frac{\sigma_{\mathrm{bs}, \lambda}}{\sigma_{\mathrm{s}, \lambda}}$.

The single scattering albedo, $\omega_{\lambda}$, is the ratio of the scattering coefficient to the extinction coefficient at a given wavelength. Here, $\omega_{\lambda}$ at a certain $\lambda$ can be calculated as follows:

$\omega_{\lambda}=\frac{\sigma_{\mathrm{s}, \lambda}}{\sigma_{\mathrm{s}, \lambda}+\sigma_{\mathrm{a}, \lambda}}$.

Because $\sigma_{\mathrm{a}}$ was not measured at $550 \mathrm{~nm}$ by an aethalometer, $\sigma_{\mathrm{a}}$ at $\lambda=520 \mathrm{~nm}$ is converted to $\sigma_{\mathrm{a}}$ at $\lambda=550 \mathrm{~nm}$ as follows:

$\sigma_{\mathrm{a}, 500}=\sigma_{\mathrm{a}, 520} \cdot\left(\frac{\lambda(550 \mathrm{~nm})}{\lambda(520 \mathrm{~nm})}\right)^{-\propto}$,

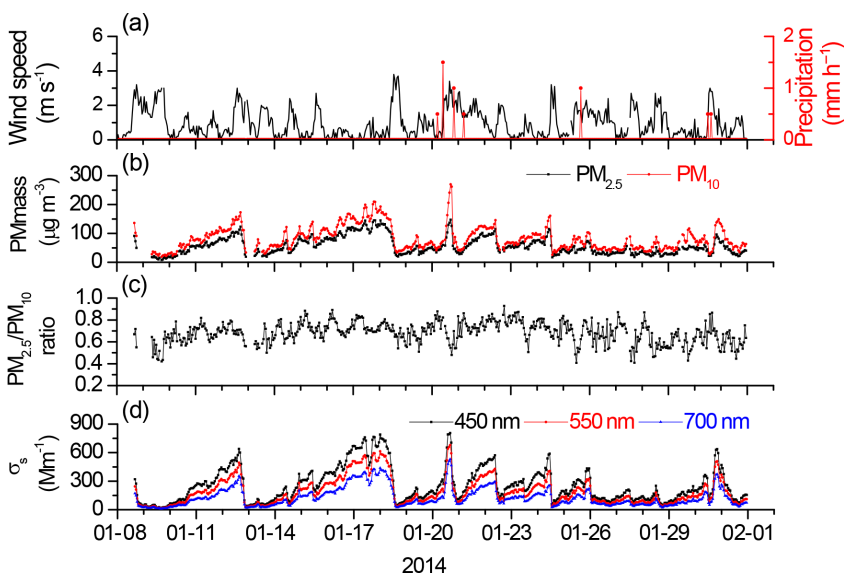

Figure 2. Temporal variations in (a) hourly average wind speed and precipitation, (b) $\mathrm{PM}_{2.5}$ and $\mathrm{PM}_{10}$ mass concentrations, (c) $\mathrm{PM}_{2.5} / \mathrm{PM}_{10}$ mass ratio, and light scattering coefficient $\left(\sigma_{\mathrm{S}}\right)$ at 450, 550, and $700 \mathrm{~nm}$ at the Daejeon site during January 2014.

where $\alpha$ is the absorbing Ångström exponent, which was determined from spectral aerosol light absorption as follows:

$\propto=-\frac{\log \left(\sigma_{\mathrm{a}, 590}\right)-\log \left(\sigma_{\mathrm{a}, 520}\right)}{\log (590 \mathrm{~nm})-\log (520 \mathrm{~nm})}$.

The mass scattering efficiency, $\mathrm{MSE}_{\lambda}$, is the ratio of the scattering coefficient to the mass concentrations at a given wavelength, expressed as

$\mathrm{MSE}_{\lambda}=\frac{\sigma_{\mathrm{s}, \lambda}}{\mathrm{PM}_{2.5} \text { mass }}$.

\section{Results and discussion}

\subsection{Temporal variations in PM mass and light scattering coefficient $\left(\sigma_{\mathrm{s}}\right)$}

Figure 2 shows temporal variations in wind speed and hourly precipitation, $\mathrm{PM}_{10}$ and $\mathrm{PM}_{2.5}$ mass, the $\mathrm{PM}_{2.5} / \mathrm{PM}_{10}$ mass ratio, and the light scattering coefficient $\left(\sigma_{\mathrm{s}}\right)$ at the measurement site in Daejeon during 8-31 January 2014. The $\mathrm{PM}_{10}$ mass concentrations ranged from 19 to $270 \mu \mathrm{g} \mathrm{m}^{-3}$ with an average of $83 \pm 42 \mu \mathrm{g} \mathrm{m}^{-3}$, and $\mathrm{PM}_{2.5}$ mass concentrations ranged from 8 to $147 \mu \mathrm{g} \mathrm{m}^{-3}$ with an average of $57 \pm 30 \mu \mathrm{g} \mathrm{m}^{-3}$ during the measurement period. The average $\mathrm{PM}_{2.5}$ mass concentration in this study is much higher than the US EPA NAAQS (National Ambient Air Quality Standards) for $\mathrm{PM}_{2.5}$ of $35 \mu \mathrm{g} \mathrm{m}^{-3}$ ( $24 \mathrm{~h}$ average). Average $\mathrm{PM}_{2.5} / \mathrm{PM}_{10}$ mass ratios ranged from 0.41 to 0.93 with an average of $0.68 \pm 0.1 . \sigma_{\mathrm{s}}$ at $550 \mathrm{~nm}$ ranged from 12.7 to $678.4 \mathrm{Mm}^{-1}$ with an average of $189.1 \pm 142.0 \mathrm{Mm}^{-1}$. The average $\sigma_{\mathrm{s}}$ in this study is comparable with the annual mean of $217 \mathrm{Mm}^{-1}$ measured in the Shanghai region, China, during 2010-2012 (Cheng et al., 2015) but is lower than the annual mean of $360 \mathrm{Mm}^{-1}$ in the Beijing region, China, mea- 
sured during 2009-2010 (Jing et al., 2015). Because light scattering is caused mainly by aerosol particles and the scattering measurements of the present study were performed under dry conditions $(\mathrm{RH}<30 \%)$, similar temporal patterns were observed for PM mass and $\sigma_{\mathrm{s}}$ (Fig. 2).

As shown in Fig. 2, three haze episodes were observed on 12, 17, and 20 January 2014 with peak $\mathrm{PM}_{10}$ mass concentrations of 173,210 , and $270 \mu \mathrm{g} \mathrm{m}^{-3}$, respectively. $\mathrm{PM}_{2.5} / \mathrm{PM}_{10}$ mass ratios during the episodes were measured as $0.71,0.69$, and 0.54 , respectively, during the three episodes. The first and second haze episodes were caused mainly by the accumulation of pollutants for 3-4 days under stagnant atmospheric conditions with relatively low wind speed $\left(<1 \mathrm{~m} \mathrm{~s}^{-1}\right)$ (Fig. 2). After 3-4 days of aerosol accumulation, PM mass concentrations showed a sharp decrease with relatively high wind speeds $\left(>2 \mathrm{~m} \mathrm{~s}^{-1}\right)$. A sharp increase in $\mathrm{PM}_{10}$ mass was observed during the third episode when a relatively high wind speed was observed (Fig. 2a). A similar temporal pattern was observed for $\sigma_{\mathrm{s}}$ and $\mathrm{PM}_{10}$ mass concentrations during the three haze episodes. The light scattering coefficient at $550 \mathrm{~nm}$ reached peak values of 494.2 , 594.4, and $678.4 \mathrm{Mm}^{-1}$ during the first, second, and third episodes, respectively (Fig. 2d).

During the first and second haze episodes, no precipitation was observed, whereas before and after the third haze episode light precipitation was observed with an hourly average of $0.5-1.5 \mathrm{~mm} \mathrm{~h}^{-1}$. Sharp decrease of $\sigma_{\mathrm{s}}$ and $\mathrm{PM}_{10}$ mass concentrations during the third haze episode was mainly attributed to precipitation. However, the first and second haze episodes were not influenced by precipitation.

\subsection{Single scattering albedo $(\omega)$, Ångström exponent $(\AA)$, and backscattering fraction $(b)$}

Figure 3 shows temporal variations in aerosol optical properties, including $\sigma_{\mathrm{s}}, \AA$, backscattering fraction $(b)$, and $\omega$. The $\AA$ value between 450 and $700 \mathrm{~nm}(\AA(450 / 700))$ ranged from 0.94 to 1.99 with an average of $1.60 \pm 0.19$, which is comparable to the $\AA(450 / 550)$ value of $1.59 \pm 0.21$ and $\AA(550 / 700)$ value of $1.61 \pm 0.19$ listed in Table 1 . The $\AA(450 / 700)$ value obtained in this study is slightly higher than that obtained in Beijing, China, during summer 2006 (1.42 \pm 0.19 ; Garland et al., 2009) and that obtained in Guangzhou, China, during summer 2006 (1.51 \pm 0.20 ; Garland et al., 2008). Because $\AA$ is negatively correlated with particle diameter (Eck et al., 1999), the slightly higher $\AA$ observed in this study compared with those from mainland China implies larger aerosol particles in this study.

During the measurement period, $b$ at $550 \mathrm{~nm}\left(b_{550}\right)$ ranged from 0.08 to 0.17 with an average of $0.12 \pm 0.02$, which is comparable with $b_{450}(0.12 \pm 0.02)$ but slightly lower than $b_{700}(0.15 \pm 0.02)$. Similar patterns of $b$ with wavelength were observed in Beijing owing to a decrease in particle size with increasing wavelength (Garland et al., 2009). The $\omega$ at $550 \mathrm{~nm}\left(\omega_{550}\right)$ ranged from 0.58 to 0.95 with an average

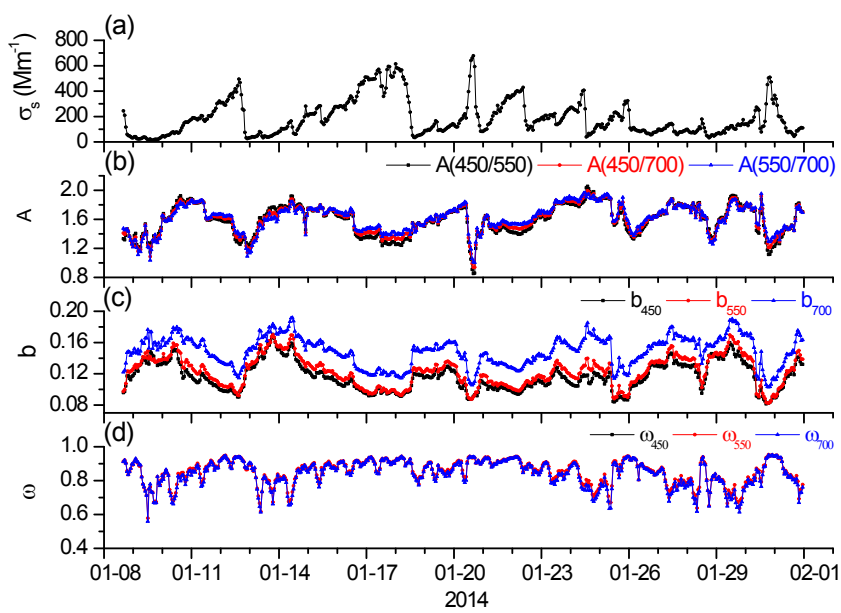

Figure 3. Temporal variations in (a) hourly average $\sigma_{\mathrm{s}, 550}$, (b) the Ångström exponent of $\sigma_{\mathrm{s}}(\AA)$, (c) the backscattering fraction $(b)$, and single scattering albedo $(\omega)$ at 450,550 , and $700 \mathrm{~nm}$. $\AA(450 / 550)$ represents the Angström exponent calculated from $\sigma_{\mathrm{S}}$ at 450 and $550 \mathrm{~nm}$.

of $0.85 \pm 0.07$, which is comparable with $\omega_{450}(0.85 \pm 0.07)$ and $\omega_{700}(0.84 \pm 0.08)$. The average $\omega_{550}$ is close to the values reported from other locations in and around Beijing and Guangzhou $\left(\omega_{550}=0.82-0.85\right)$ (Bergin et al., 2001; Andreae et al., 2008; Cheng et al., 2008; Garland et al., 2008, 2009).

Dynamic temporal patterns in $\AA, b$, and $\omega$ were observed during the measurement period (Fig. 3). Gradual decreases in $\AA$ with increasing $\sigma_{\mathrm{s}}$ were observed during the first and second haze episodes, whereas a sharp decrease in $\AA$ was observed with increasing $\sigma_{\mathrm{s}}$ during the third episode. It was also found that $b$ was negatively correlated with $\sigma_{\mathrm{s}}$ during the three episodes. Meanwhile, $\omega$ increased gradually with $\sigma_{\mathrm{s}}$ during the first and second episodes. These results indicate that temporal variations in $\AA, b$, and $\omega$ are closely related to those in $\sigma_{\mathrm{s}}$. In this study, $\AA$ and $b$ were negatively correlated with $\sigma_{\mathrm{s}}$, whereas $\omega$ was positively correlated with $\sigma_{\mathrm{s}}$.

Figure 4 clearly shows that $\omega_{550}$ increases with $\sigma_{\mathrm{s}, 550}$. When $\omega_{550}$ was less than $200 \mathrm{Mm}^{-1}, \omega_{550}$ varied widely from 0.6 to $>0.9$. The $\AA(450 / 700)$ value increased with $\sigma_{\mathrm{s}, 550}$ when $\sigma_{\mathrm{s}, 550}$ was lower than $\sim 150 \mathrm{Mm}^{-1}$. However, when $\sigma_{\mathrm{s}, 550}$ was higher than $\sim 150 \mathrm{Mm}^{-1}, \AA(450 / 700)$ gradually decreased with increasing $\sigma_{\mathrm{s}, 550}$. Figure $5 \mathrm{a}$ shows a scatter plot of $\omega_{550}$ versus $b_{550}$ as a function of $\sigma_{\mathrm{s}, 550}$, where $\omega_{550}$ is observed to decrease as $b_{550}$ increases. A scatter plot of $b_{550}$ versus $\AA(450 / 700 \mathrm{~m})$ is shown in Fig. $5 \mathrm{~b}$. A positive correlation is observed between $\AA(450 / 700)$ and $b_{550}$ when $\sigma_{\mathrm{s}, 550}$ is higher than $200 \mathrm{Mm}^{-1}$, whereas a poor correlation is observed when $\sigma_{\mathrm{s}, 550}$ is lower than $200 \mathrm{Mm}^{-1}$. In addition, a relatively small $b_{550}$ is observed as $\sigma_{\mathrm{s}, 550}$ increases (Fig. 5a and b). 
Table 1. Summary of aerosol optical parameters observed in Daejeon, South Korea, during January 2014.

\begin{tabular}{|c|c|c|}
\hline Component & Unit & Min-max (average $\pm S D)$ \\
\hline Light scattering coefficient, $\sigma_{\mathrm{s}, 450}$ & $\mathrm{Mm}^{-1}$ & $16.5-805.0(256.9 \pm 183.7)$ \\
\hline$\sigma_{\mathrm{s}, 550}$ & $\mathrm{Mm}^{-1}$ & $12.7-678.4(189.1 \pm 142.0)$ \\
\hline$\sigma_{\mathrm{s}, 700}$ & $\mathrm{Mm}^{-1}$ & $9.3-531.6(129.1 \pm 101.3)$ \\
\hline Backscattering coefficient, $\sigma_{\mathrm{bs}, 450}$ & $\mathrm{Mm}^{-1}$ & $2.4-77.2(27.6 \pm 16.9)$ \\
\hline$\sigma_{\mathrm{bs}, 550}$ & $\mathrm{Mm}^{-1}$ & $1.7-61.3(21.3 \pm 13.3)$ \\
\hline$\sigma_{\mathrm{bs}, 700}$ & $\mathrm{Mm}^{-1}$ & $1.4-57.2(17.8 \pm 11.7)$ \\
\hline Ångström exponent of $\sigma_{\mathrm{s}}, \AA(450 / 550)$ & & $0.85-2.06(1.59 \pm 0.21)$ \\
\hline$\AA(450 / 700)$ & & $0.94-1.99(1.60 \pm 0.19)$ \\
\hline$\AA(550 / 700)$ & & $1.0-1.97(1.61 \pm 0.19)$ \\
\hline Hemispheric backscattering fraction, $b_{450}$ & & $0.08-0.17(0.12 \pm 0.02)$ \\
\hline$b_{550}$ & & $0.08-0.17(0.12 \pm 0.02)$ \\
\hline$b_{700}$ & & $0.1-0.19(0.15 \pm 0.02)$ \\
\hline Single scattering albedo, $\omega_{450}$ & & $0.57-0.95(0.85 \pm 0.07)$ \\
\hline$\omega_{550}$ & & $0.58-0.95(0.85 \pm 0.07)$ \\
\hline$\omega_{700}$ & & $0.56-0.95(0.84 \pm 0.08)$ \\
\hline
\end{tabular}

(a)

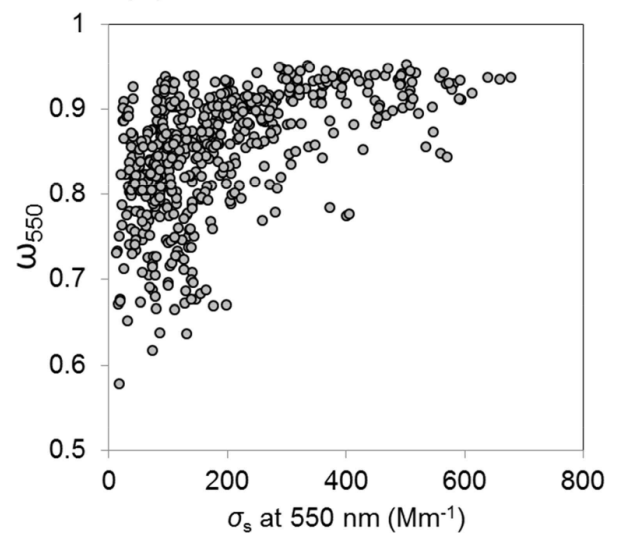

(b)

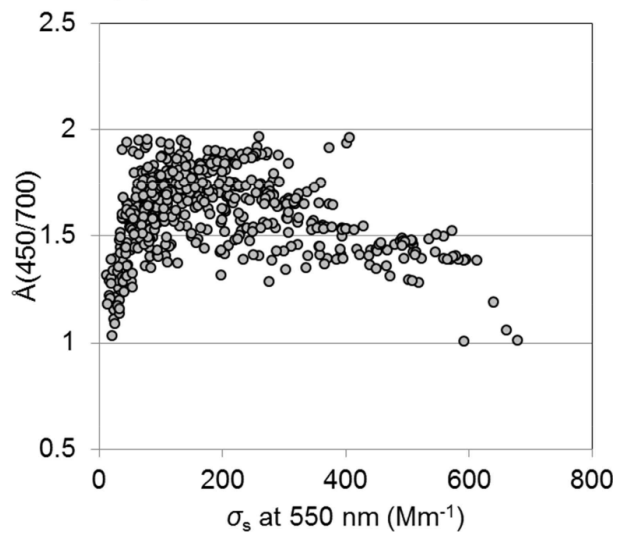

Figure 4. Scatter plot of $\sigma_{\mathrm{s}, 550}$ versus (a) $\omega_{550}$ and (b) $\AA(450 / 700)$ during the entire measurement period.

\subsection{Aerosol optical properties during severe haze episodes}

\subsubsection{Classification of haze episodes}

As shown in Fig. 2b, three haze episodes were observed during 11-12, 14-17, and 20 January 2014. This study defines haze episodes when $\mathrm{PM}_{2.5}$ mass concentration is higher than $80 \mu \mathrm{g} \mathrm{m}^{-3}$ or $\mathrm{PM}_{10}$ mass concentration is higher than $150 \mu \mathrm{g} \mathrm{m}^{-3}$. These threshold values of the haze episode correspond to visibility of $\sim 8 \mathrm{~km}$ estimated by Jung et al. (2009b). This study focused on the second and third haze episodes, which peaked on 17 and 20 January 2014. Figure 6 shows MODIS RGB images during 14-17 January 2014. A dense haze layer is clearly seen over east China during 14 January. This layer moved slowly to the Korean Peninsula from 15 to 17 January. Air mass backward trajectories ending at the measurement site also show the transport of air masses from east China to the Korean Peninsula on 17 January 2014, as shown in Fig. 7a. During the second haze episode, very low wind speeds of $<1 \mathrm{~m} \mathrm{~s}^{-1}$ were observed (Fig. 2a). Thus, the second haze episode is classified as a period of accumulation of LRT pollutants from the Asian continent (LRT haze).

During the third haze episode on 20 January, very high concentrations of $\mathrm{Ca}$ (maximum: $9.4 \mu \mathrm{g} \mathrm{m}^{-3}$, average: $3.2 \pm 3.4 \mu \mathrm{g} \mathrm{m}^{-3}$ ) were observed (Table 2). The air mass backward trajectory for 20 January clearly shows that the air mass originating from the Inner Mongolia desert area had an impact on the Korean Peninsula (Fig. 7b). During the third haze episode, relatively high wind speeds of $>2 \mathrm{~m} \mathrm{~s}^{-1}$ were observed (Fig. 2a). Thus, the third haze episode is classified as an Asian dust episode. 
(a)

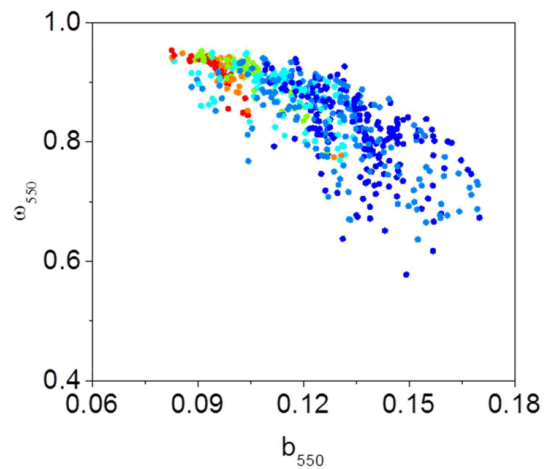

(b)

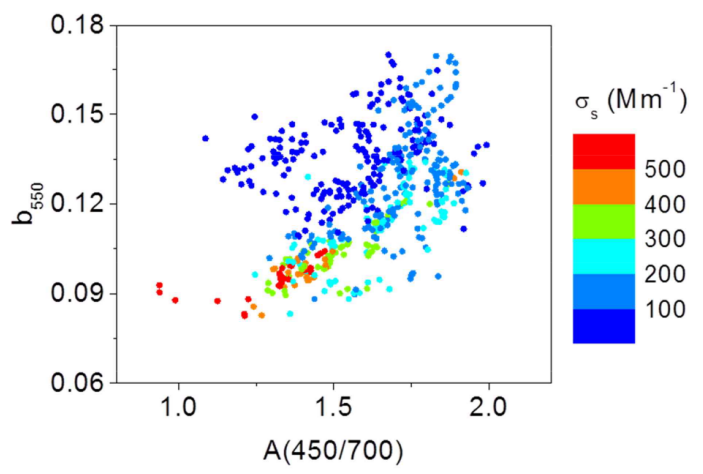

Figure 5. Scatter plots of (a) $b_{550}$ versus $\omega_{550}$ and (b) $\AA(450 / 700)$ versus $b_{550}$ as a function of $\sigma_{\mathrm{s}, 550}$.

Table 2. Comparison of PM mass, chemical components, and intensive optical properties during long-range transported (LRT) haze and Asian dust episodes observed at Daejeon, South Korea, during January 2014.

\begin{tabular}{lrr}
\hline & \multicolumn{2}{c}{ LRT haze $^{\mathrm{a}}$} \\
\cline { 2 - 3 } & \multicolumn{2}{c}{ Msian dust $^{\mathrm{b}}$} \\
\hline $\mathrm{PM}_{10}\left(\mu \mathrm{g} \mathrm{m}^{-3}\right)$ & $133-210(163.9 \pm 25.0)$ & $126-270(211.3 \pm 57.5)$ \\
$\mathrm{PM}_{2.5}\left(\mu \mathrm{g} \mathrm{m}^{-3}\right)$ & $100-145(121.6 \pm 12.8)$ & $86-147(121.5 \pm 22.7)$ \\
$\mathrm{PM}_{2.5} / \mathrm{PM}_{10}$ ratio & $0.68-0.84(0.75 \pm 0.06)$ & $0.48-0.68(0.59 \pm 0.06)$ \\
$\mathrm{EC} / \mathrm{PM}_{10}$ ratio & $0.026-0.047(0.033 \pm 0.006)$ & $0.023-0.032(0.026 \pm 0.003)$ \\
$\mathrm{Ca}\left(\mu \mathrm{g} \mathrm{m}^{-3}\right)$ & $0.02-0.3(0.2 \pm 0.1)$ & $0.2-9.4(3.2 \pm 3.4)$ \\
$\sigma_{\mathrm{s}, 550}\left(\mathrm{Mm}^{-1}\right)$ & $358.8-594.4(503.4 \pm 60.5)$ & $276.1-678.4(560.9 \pm 151)$ \\
$\sigma_{\mathrm{a}, 550}\left(\mathrm{Mm}^{-1}\right)$ & $29.3-105.4(51.9 \pm 21.9)$ & $29.4-46.1(39.4 \pm 7.3)$ \\
$\AA(450 / 700)$ & $1.30-1.47(1.39 \pm 0.05)$ & $0.94-1.25(1.08 \pm 0.14)$ \\
$\omega_{550}$ & $0.84-0.94(0.91 \pm 0.03)$ & $0.90-0.94(0.92 \pm 0.02)$ \\
\hline
\end{tabular}

a LRT haze: 17 January 2014, 00:00-23:00 LT. ${ }^{\text {b }}$ Asian dust: 20 January 2014, 13:00-18:00 LT.
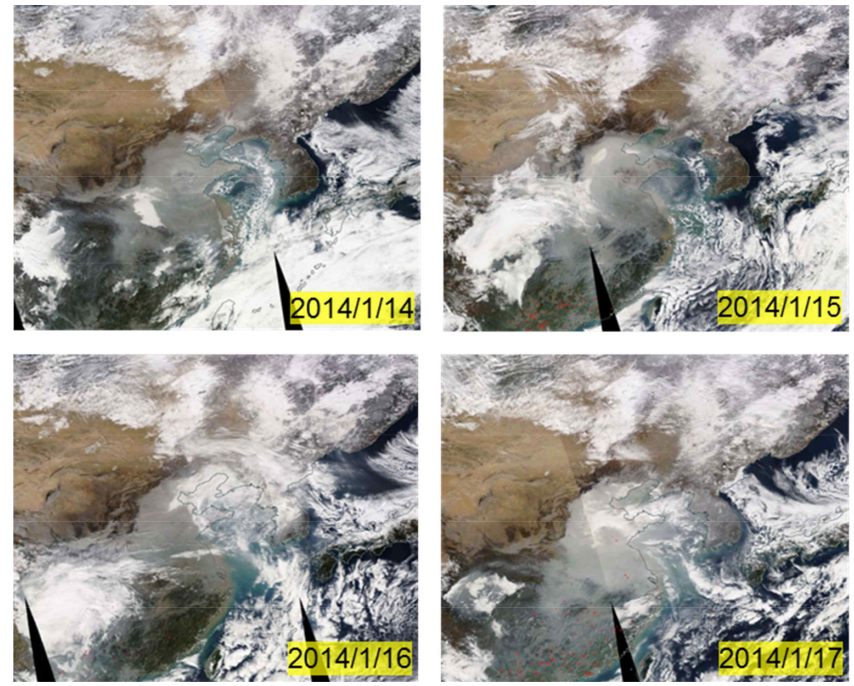

Figure 6. MODIS RGB images over east Asia during 14-17 January 2014 .

\subsubsection{Temporal variations in the chemical and optical properties of LRT haze}

Figure 8 shows temporal variations in the chemical composition of $\mathrm{PM}_{2.5}$ during the LRT haze episode (14-17 January 2014). As mentioned above, the LRT haze episode was caused mainly by the accumulation of long-range transported pollutants from the Asian continent. Gradual increases in total $\mathrm{PM}_{2.5}$ mass were observed during the LRT haze episode (Fig. 8a). The relative contribution of $\mathrm{PM}_{2.5}$ chemical composition is also shown in Fig. 8b. Organic aerosol (OA) dominated the $\mathrm{PM}_{2.5}$ mass composition, followed by $\mathrm{NO}_{3}^{-}, \mathrm{SO}_{4}^{2-}$, and $\mathrm{NH}_{4}^{+}$. Even though a small decrease in OA mass fraction was observed during 15 January, the mass fractions of the major $\mathrm{PM}_{2.5}$ chemical components were invariant from 14 to 17 January. These results suggest that the increase in $\mathrm{PM}_{2.5}$ mass concentration observed during the LRT haze episode was caused mainly by the accumulation of LRT pollutants.

Figure 9 shows temporal variations in the daily average intensive optical properties of the LRT haze. The $\AA(450 / 700)$ and $b_{550}$ values decreased during the accumulation period 
(a)

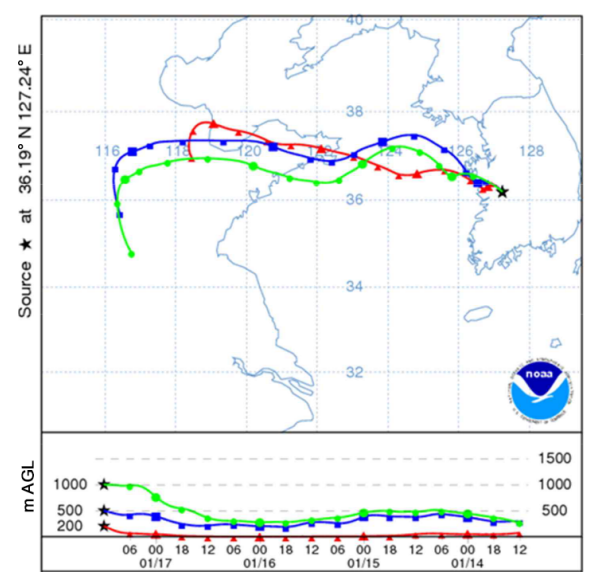

(b)

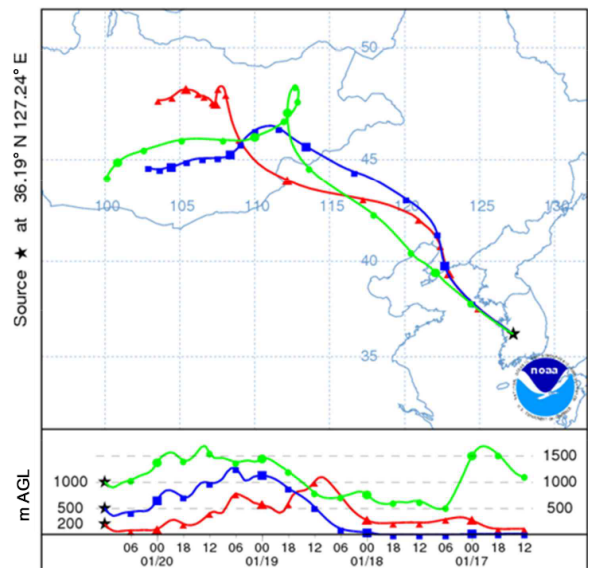

Figure 7. Air mass backward trajectories arriving at the measurement site on (a) 16 and (b) 20 January 2014. Red, blue, and green lines represent backward trajectories arriving at heights of 200,500 , and $1000 \mathrm{~m}$, respectively.

(a)

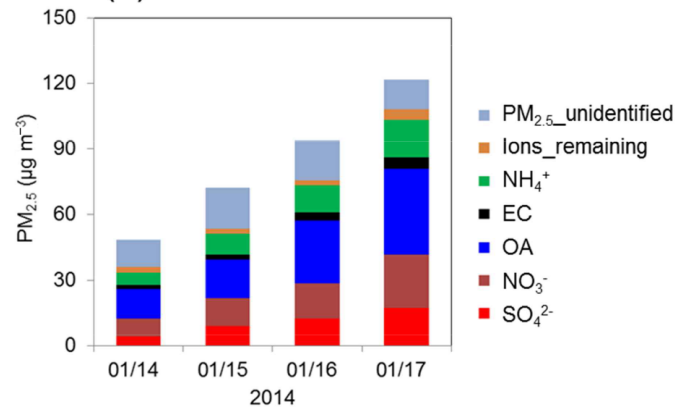

(b)

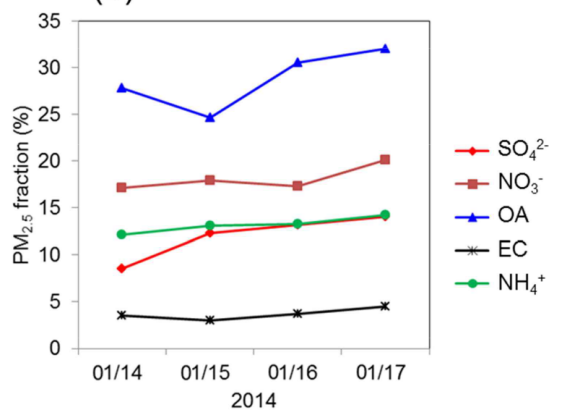

Figure 8. Temporal variations in (a) mass concentrations of $\mathrm{PM}_{2.5}$ chemical components and (b) $\mathrm{PM}_{2.5}$ mass fractions of major components during 14-17 January 2014.

from 14 to 17 January, while $\mathrm{MSE}_{550}$ and $\omega_{550}$ increased. Average $\AA(450 / 700)$ decreased from $1.74 \pm 0.09$ on 14 January to $1.39 \pm 0.05$ on 17 January. Average $b_{550}$ decreased from $0.15 \pm 0.01$ on 14 January to $0.10 \pm 0.003$ on 17 January. Average $\mathrm{MSE}_{550}$ of $\mathrm{PM}_{10}$ increased from $1.73 \pm 0.40 \mathrm{~m}^{2} \mathrm{~g}^{-1}$ on 14 January to $3.11 \pm 0.46 \mathrm{~m}^{2} \mathrm{~g}^{-1}$ on 17 January. An increase in $\mathrm{MSE}_{550}$ with increasing PM mass concentration during the haze episodes was also observed in Beijing and Guangzhou, China, during summer 2006 (Jung et al., 2009a, b). For example, in Beijing the $\mathrm{MSE}_{550}$ of $\mathrm{PM}_{10}$ increased from $1.4 \pm 0.89 \mathrm{~m}^{2} \mathrm{~g}^{-1}$ during relatively clean conditions to $3.1 \pm 0.9 \mathrm{~m}^{2} \mathrm{~g}^{-1}$ during relatively polluted conditions (Jung et al., 2009a). At most monitoring sites in the United States, dry MSE increased with increasing mass concentration (IMPROVE, 2006).

Average $\omega_{550}$ increased from $0.81 \pm 0.07$ on 14 January to $0.90 \pm 0.03$ on 17 January. A similar pattern was observed as pollution increased in Beijing during summer 2006 (Jung et al., 2009a). Average $\omega_{550}$ increased from $\sim 0.75$ during relatively clean conditions to $\sim 0.86$ during relatively polluted conditions in Beijing during summer 2006 owing to an increase in $\mathrm{SO}_{4}^{2-}, \mathrm{NO}_{3}^{-}, \mathrm{NH}_{4}^{+}$, and organic aerosols (Jung et al., 2009a). Because EC is a strong light-absorbing aerosol, changes in EC mass fraction in $\mathrm{PM}_{2.5}$ mass can be used as an indicator of $\omega$. As shown in Fig. 8b, EC mass fraction in $\mathrm{PM}_{2.5}$ was invariant from 14 to 17 January. These results indicate that an increase in mass concentration of secondary aerosols such as $\mathrm{SO}_{4}^{2-}, \mathrm{NO}_{3}^{-}, \mathrm{NH}_{4}^{+}$, and secondary organic aerosol cannot explain the increase in $\omega_{550}$ under stagnant conditions during the LRT haze episode. On the other hand, an increase in $\mathrm{MSE}_{550}$ under stagnant conditions (Fig. 9b) can enhance $\omega_{550}$, resulting in an increase in $\omega_{550}$ under stagnant conditions.

The amount of light scattered by aerosol particles can be accurately estimated using Mie theory when the size distribution and refractive index of the particles are known (Mie, 1908; Hess et al., 1998; Seinfeld and Pandis, 1998). Light scattering efficiencies of $\left(\mathrm{NH}_{4}\right)_{2} \mathrm{SO}_{4}$ and organic aerosols at $550 \mathrm{~nm}$ were calculated using Mie theory using refractive indices for $1.53-0 i$ and $1.55-0 i$, respectively (Liu et al., 


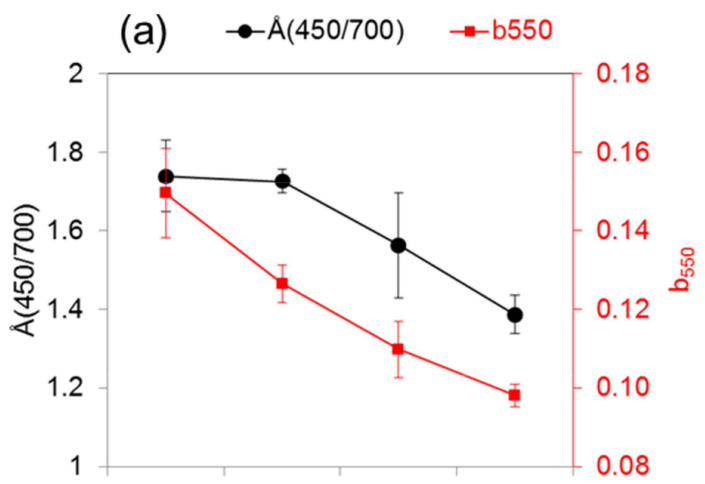

(b)

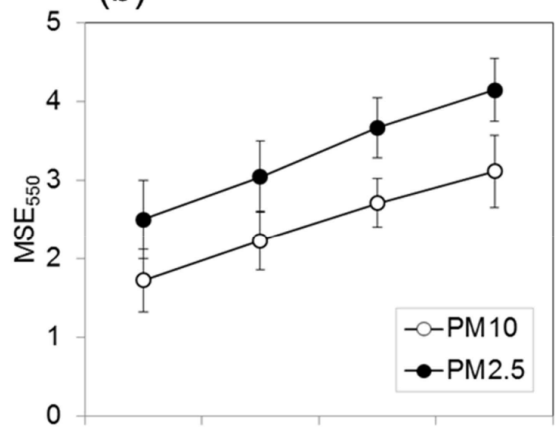

(c)

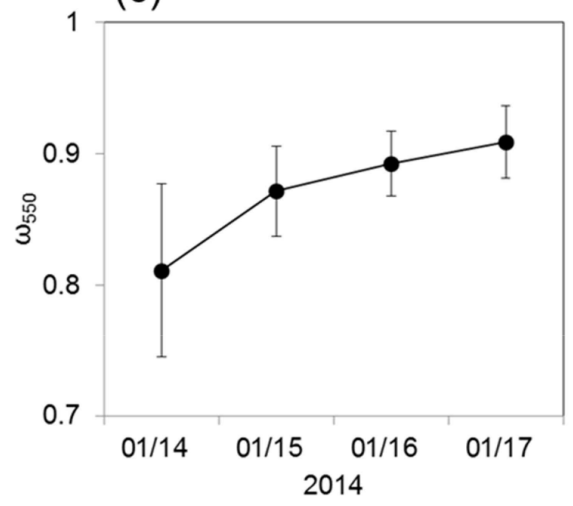

Figure 9. Temporal variations in (a) daily average $\AA(450 / 700)$ and $b_{550}$, (b) mass scattering efficiency at $550 \mathrm{~nm}\left(\mathrm{MSE}_{550}\right)$, and (c) $\omega_{550}$ during 14-17 January 2014.

2009), as shown in Fig. 10. Light scattering efficiencies of $\left(\mathrm{NH}_{4}\right)_{2} \mathrm{SO}_{4}$ and organic aerosols at $550 \mathrm{~nm}$ increase as particle size increases to $600 \mathrm{~nm}$.

Freshly formed aerosol particles have a diameter $\left(D_{\mathrm{p}}\right)$ of less than $100 \mathrm{~nm}$ (Yue et al., 2010) and grow into the accumulation mode $\left(100 \mathrm{~nm}<D_{\mathrm{p}}<1000 \mathrm{~nm}\right)$ through the condensation of gas vapors or coagulation (collisions between particles; Seinfeld and Pandis, 1998). Thus, larger particles (in the accumulation mode) are observed under polluted stagnant conditions. An increase in $D_{\mathrm{p}}$ under stagnant conditions can enhance light scattering, resulting in an increase in MSE. $\AA$ and $b$ are also closely related to the size of aerosol particles. For example, Eck et al. (1999) reported that coarse-mode par-

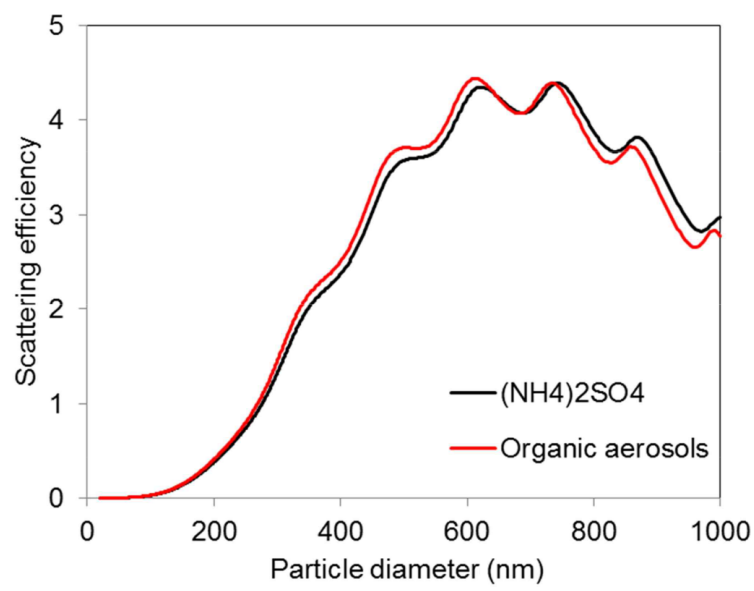

Figure 10. Scattering efficiency of $\left(\mathrm{NH}_{4}\right)_{2} \mathrm{SO}_{4}$ and organic aerosols as a function of particle diameter, as calculated from Mie theory.

ticles had relatively low $\AA$ compared with fine-mode particles. Nemesure et al. (1995) reported that the forward scattering fraction increases as particle size increases, resulting in a decrease in $b$. This suggests that the temporal variations in intensive optical properties shown in Fig. 9 are closely related to the change in size of aerosol particles under stagnant conditions.

Because the LRT haze from the Asian continent reached the Korean Peninsula on 14 January, as shown in Fig. 6, aerosol optical properties on 14 January can be used to evaluate aerosol mixing state or aging during the atmospheric transport. When intensive optical properties of aerosols on 14 January were compared with those obtained at the air mass source regions in China, no big difference between them was observed. For example, $\mathrm{MSE}_{550}$ of $\mathrm{PM}_{10}$ $\left(1.73 \pm 0.40 \mathrm{~m}^{2} \mathrm{~g}^{-1}\right)$ on 14 January was similar to those $\left(1.4 \pm 0.89 \mathrm{~m}^{2} \mathrm{~g}^{-1}\right)$ during relatively clean condition in Beijing, China, but much lower than those $\left(3.1 \pm 0.9 \mathrm{~m}^{2} \mathrm{~g}^{-1}\right)$ during relatively polluted conditions (Jung et al., 2009a). $\omega_{550}(0.81 \pm 0.07)$ on 14 January was also similar to those $(\sim 0.75)$ during relatively clean conditions in Beijing. These results imply that aerosol aging is insignificant during the atmospheric transport from China to the Korean Peninsula in winter.

\subsubsection{Intercomparison of the aerosol optical properties of LRT haze versus Asian dust particles}

Optical properties of the LRT haze and Asian dust are compared in Fig. 11 and summarized in Table 2. For this comparison, data obtained on 17 January were used to represent aged LRT haze. Elevated Ca concentrations were observed during the Asian dust episode, with an average of $3.2 \pm 3.4 \mu \mathrm{g} \mathrm{m}^{-3}$. Similar levels of $\mathrm{PM}_{2.5}$ mass were obtained during the LRT haze and Asian dust episodes, whereas much higher $\mathrm{PM}_{10}$ mass was obtained during the Asian dust episode 
(a)

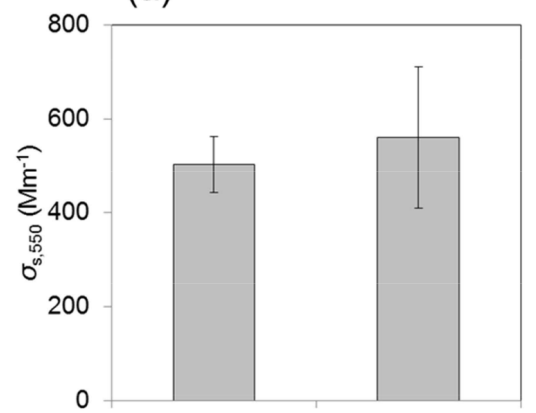

(c)

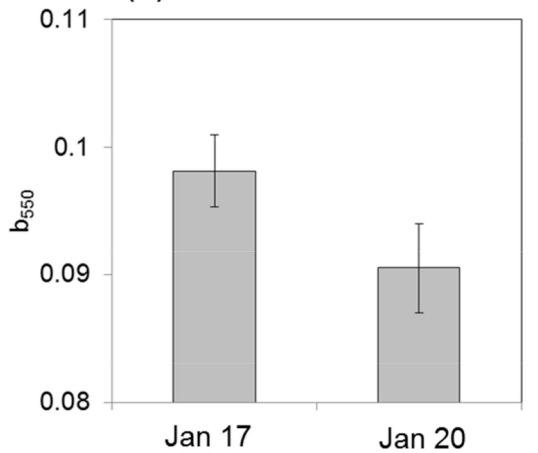

(b)

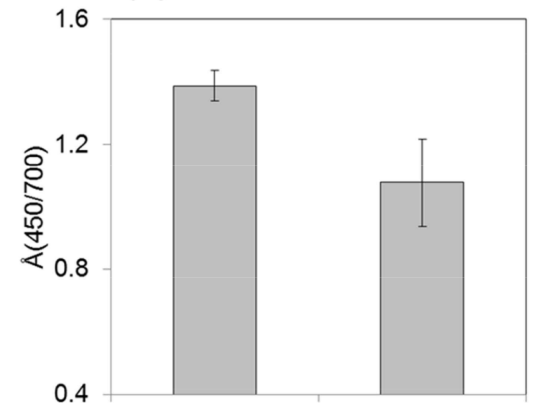

(d)

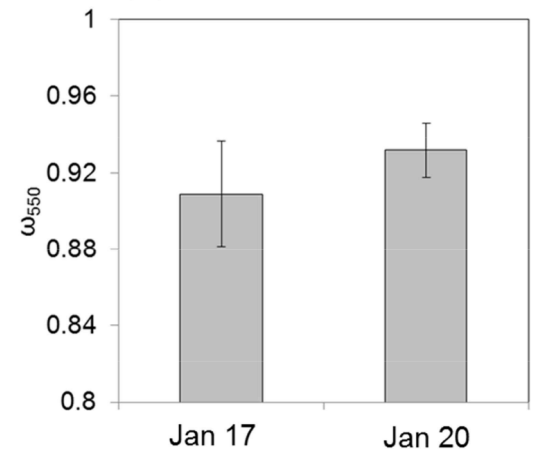

Figure 11. Comparison of (a) average $\sigma_{\mathrm{s}, 550}$ during the severe long-range transported haze episode (17 January) and during the Asian dust episode (20 January). Comparisons of $\AA(450 / 700), b_{550}$, and $\omega_{550}$ are shown in (b), (c), and (d), respectively.

compared with the LRT haze episode (Table 2), resulting in higher $\mathrm{PM}_{2.5} / \mathrm{PM}_{10}$ mass ratios during the LRT haze episode $(0.75 \pm 0.0)$ compared with the Asian dust episode $(0.59 \pm 0.06)$. Higher $\mathrm{EC} / \mathrm{PM}_{10}$ mass ratios were observed during the LRT haze episode with an average of $0.033 \pm 0.00$ compared with the Asian dust episode $(0.026 \pm 0.003)$. $\mathrm{PM}_{2.5} / \mathrm{PM}_{10}$ mass ratios and $\mathrm{EC} / \mathrm{PM}_{10}$ mass ratios during the Asian dust episode were higher than those obtained in Seoul, South Korea, during severe Asian dust episodes in 2007-2008 $\left(\mathrm{PM}_{2.5} / \mathrm{PM}_{10}<0.4 ; \mathrm{EC} / \mathrm{PM}_{10}<0.013\right)$. In addition, high $\mathrm{PM}_{2.5}$ mass concentrations during the Asian dust episode in this study suggest that Asian dust particles mixed with LRT haze originating from anthropogenic emissions had an impact on the measurement site on 20 January.

Similar levels of $\sigma_{\mathrm{s}}$ were observed during the LRT haze $\left(503.4 \pm 60.5 \mathrm{Mm}^{-1}\right)$ and Asian dust episode $\left(560.9 \pm 151 \mathrm{Mm}^{-1}\right)$ (Fig. 11a). The $\omega_{550}$ values obtained for the two episodes were comparable, with averages of $0.91 \pm 0.03$ and $0.92 \pm 0.0$ observed during the LRT haze and Asian dust episodes, respectively. However, a higher light absorption coefficient $\left(\sigma_{\mathrm{a}, 550}\right)$ was obtained during the LRT haze episode $\left(51.9 \pm 21.9 \mathrm{Mm}^{-1}\right)$ compared with the Asian dust episode $\left(39.4 \pm 7.3 \mathrm{Mm}^{-1}\right)$. Higher $\AA(450 / 700)$ was obtained during the LRT haze episode (average of $1.39 \pm 0.05$ ) compared with the Asian dust episode $(1.08 \pm 0.14)$, due mainly to the relatively large size distribution during the Asian dust episode. The results of this study suggest that $\mathrm{PM}_{2.5} / \mathrm{PM}_{10}$ mass ratios and $\AA(450 / 700)$ can be used as tracers to distinguish aged LRT haze and Asian dust based on differences in the particle size distribution. This study suggests that $\mathrm{PM}_{2.5} / \mathrm{PM}_{10}$ mass ratio and $\AA(450 / 700)$ of $<0.6$ and $<1.0$, respectively, can be used as the cut-off points to indicate Asian dust mixed with haze.

\section{Conclusions}

An intensive field campaign was conducted at an area downwind of the Asian continental outflow (Daejeon, South Korea) during winter 2014 to characterize the spectral optical properties of severe haze episodes. Dynamic temporal patterns of aerosol optical properties were observed during the measurement period. During the stagnant period (13-17 January 2014), after long-range transport of haze from the Asian continent, no significant change in the mass fraction of $\mathrm{PM}_{2.5}$ chemical composition was observed, with the highest fraction being organic aerosol, followed by $\mathrm{NO}_{3}^{-}, \mathrm{NH}_{4}^{+}$, and $\mathrm{SO}_{4}^{2-}$. On the other hand, a gradual decrease in Ångström exponent $(\AA)$ and gradual increases in single scattering albedo $(\omega)$ and mass scattering efficiency (MSE) were observed during the stagnant period. Mie calculations suggest that the increase in aerosol particle diameter under stagnant conditions enhanced light scattering, resulting in an increase in MSE. 
It is also suggested that the increase in MSE under stagnant conditions enhanced $\omega$. These results imply that change in particle size rather than chemical composition during the stagnant period is the dominant factor affecting the aerosol optical properties.

During the Asian dust episode, very high values of $\mathrm{PM}_{10}$ mass and light scattering coefficients at $550 \mathrm{~nm}, \sigma_{\mathrm{s}, 550}$, were observed with averages of $211.3 \pm 57.5 \mu \mathrm{g} \mathrm{m}^{-3}$ and $560.9 \pm 151 \mathrm{Mm}^{-1}$, respectively. The $\omega_{550}$ during the LRT haze and Asian dust episodes were comparable, with averages of $0.91 \pm 0.03$ and $0.92 \pm 0.0$, respectively, implying that aged LRT pollutants and Asian dust particles have similar $\omega$. A relatively small $\mathrm{PM}_{2.5} / \mathrm{PM}_{10}$ ratio and $\AA(450 / 700)$ were observed during the Asian dust episode compared with those during the LRT haze episode, indicating that $\mathrm{PM}_{2.5} / \mathrm{PM}_{10}$ mass ratios and $\AA(450 / 700)$ can be used as tracers to distinguish aged LRT haze and Asian dust.

The results of this study imply that severe haze episodes over the Korean Peninsula are mainly caused by long-range transported pollutants from the Asian continent. These severe haze episodes can be elevated under the stagnant atmospheric condition. It is postulated that emissions from local sources can also contribute to severe haze episodes under the stagnant atmospheric condition. Thus, the contribution of local sources to severe haze episodes needs to be classified and quantified in a future study to better understand the characteristic behavior of aerosol optical property.

Data availability. Data are available from the corresponding author on request (jsjung@kriss.re.kr).

Competing interests. The authors declare that they have no conflict of interest.

Acknowledgements. This work was conducted by a co-research project of the National Institute of Environmental Research (NIER) and the Korean Research Institute of Standards and Science (KRISS). This study was funded by the Korean Meteorological Administration Research and Development Program under grant KMIPA 2015-5020.

Edited by: N. Harris

Reviewed by: two anonymous referees

\section{References}

Aikawa, M., Toshimasa, O., Takatoshi, H., Oishi, O., Tsuji, A., Yamagami, M., Murano, K., and Mukai, H.: Significant geographic gradients in particulate sulfate over Japan determined from multiple-site measurements and a chemical transport model: Impacts of transboundary pollution from the Asian continent, Atmos. Environ., 44, 381-391, 2010.
Anderson, T. and Ogren, J.: Determining aerosol radiative properties using the TSI 3563 integrating nephelometer, Aerosol Sci. Tech., 29, 57-69, doi:10.1080/02786829808965551, 1998.

Anderson, T. L., Covert, D. S., Marshall, S. F., Laucks, M. L., Charlson, R. J., Waggoner, A. P., Ogren, J. A., Caldow, R., Holm, R. L., Quant, F. R., Sem, G. J., Wiedensohler, A., Ahlquist, N. A., and Bates, T. S.: Performance characteristics of a high sensitivity, three-wavelength, total scatter/backscatter nephelometer, J. Atmos. Ocean. Tech., 13, 967-986, 1996.

Andrea, M. O., Schmid, O., Yang, H., Chand, D., Zhen, J., Zeng, L.-M., and Zhang, Y.-H.: Optical properties and chemical composition of the atmospheric aerosol in urban Guangzhou, China, Atmos. Environ., 42, 6335-6350, 2008.

Ångström, A.: On the atmospheric transmission of sun radiation and on dust in the air, Geogr. Ann., 11, 156-166, 1929.

Bergin, M. H., Cass, G. R., Xu, J., Fang, C., Zeng, L. M., Yu, T., Salmon, L. G., Kiang, C. S., Tang, X. Y., Zhang, Y. H., and Chameides, W. L.: Aerosol radiative, physical, and chemical properties in Beijing during June 1999, J. Geophys. Res., 106, 17969-17980, doi:10.1029/2001JD900073, 2001.

Bi, J., Huang, J., Holben, B., and Zhang, G.: Comparison of key absorption and optical properties between pure and transported anthropogenic dust over East and Central Asia, Atmos. Chem. Phys., 16, 15501-15516, doi:10.5194/acp-16-15501-2016, 2016.

Birch, M. and Cary, R.: Elemental carbon-based method for monitoring occupational exposures to particulate diesel exhaust, Aerosol Sci. Tech., 25, 221-241, 1996.

Chan, C. K. and Yao, X.: Air pollution in mega cities in China, Atmos. Environ., 42, 1-42, 2008.

Cheng, T., Xu, C., Duan, J., Wang, Y., Leng, C., Tao, J., Che, H., He, Q., Wu, Y., Zhang, R., Li, X., Chen, J., Kong, L., and Yu, $\mathrm{X}$.: Seasonal variation and difference of aerosol optical properties in columnar and surface atmospheres over Shanghai, Atmos. Environ., 123, 315-326, 2015.

Cheng, Y. F., Wiedensohler, A., Eichler, H., Su, H., Gnauk, T., Brüggemann, E., Herrmann, H., Heintzenberg, J., Slanina, J., Tuch, T., Hu, M., and Zhang, Y. H.: Aerosol optical properties and related chemical apportionment at Xinken in Pearl River Delta of China, Atmos. Environ., 42, 6351-6372, 2008.

Draxler, R. and Rolph, G.: HYSPLIT (HYbrid Single-Particle Lagrangian Integrated Trajectory) Model access via NOAA ARL READY Website, available at: http://www.arl.noaa.gov/ HYSPLIT.php (last access: 2016), NOAA Air Resources Laboratory, Silver Spring, MD, 2016.

Eck, T., Holben, B., Reid, J., Dubovik, O., Smirnov, A., O’Neill, N., Slutsker, I., and Kinne, S.: Wavelength dependence of the optical depth of biomass burning, urban, and desert dust aerosols, J. Geophys. Res., 104, 31333-31349, 1999.

Gao, Y., Zhao, C., Liu, X., Zhang, M., and Leung, L.: WRF-Chem simulations of aerosols and anthropogenic aerosol radiative forcing in East Asia, Atmos. Environ., 92, 250-266, 2014.

Garland, R., Schmid, O., Nowak, A., Achtert, P., Weidensohler, A., Gunthe, S., Tekegawa, N., Kita, K., Kondo, Y., Hu, M., Shao, M., Zeng, L., Zhu, T., Andreae, M., and Pöschl, U.: Aerosol optical properties observed during Campaign of Air Quality Research in Beijing 2006 (CAREBeijing-2006): Characteristic differences between the inflow and outflow of Beijing city air, J. Geophys. Res., 114, D00G04, doi:10.1029/2008JD010780, 2009. 
Garland, R. M., Yang, H., Schmid, O., Rose, D., Nowak, A., Achtert, P., Wiedensohler, A., Takegawa, N., Kita, K., Miyazaki, Y., Kondo, Y., Hu, M., Shao, M., Zeng, L. M., Zhang, Y. H., Andreae, M. O., and Pöschl, U.: Aerosol optical properties in a rural environment near the mega-city Guangzhou, China: implications for regional air pollution, radiative forcing and remote sensing, Atmos. Chem. Phys., 8, 5161-5186, doi:10.5194/acp-85161-2008, 2008.

Gopal, K., Arafath, S., Lingaswamy, A., Balakrishnaiah, G., Kumari, S., Devi, K., Reddy, N., Reddy, K., Reddy, M., Reddy, R., and Babu, S.: In-situ measurements of atmospheric aerosols by using Integrating Nephelometer over a semi-arid station, southern India, Atmos. Environ., 86, 228-240, 2014.

Hansen, A.: The Aethalometer, manual, Berkeley, California, USA, Magee Scientific, 2005.

Hess, M., Koepke, P., and Schult, I.: Optical properties of aerosols and clouds: The software package OPAC, B. Am. Meteorol. Soc., 79, 831-844, 1998.

IMPROVE: Spatial and Seasonal Patterns and Temporal Variability of Haze and its Constituents in the United States: Report IV, available at: http://vista.cira.colostate.edu/Improve/spatial-andseasonal-patterns-and-temporal-variability-of-haze-and-itsconstituents-in-the-united-states-report-iv-november-2006/ (last access: 2016), 2006.

IPCC: Summary for policymakers, in: Climate Change 2013: the Physical Science Basis. Contribution of Working Group I to the Fifth Assessment Report of the Intergovernmental Panel on Climate Change, edited by: Stocker, T. F., Qin, D., Plattner, G.-K., Tignor, M., Allen, S. K., Boschung, J., Nauels, A., Xia, Y., Bex, V., and Midgley, P. M., Cambridge, United Kingdom and New York, NY, USA, 2013.

Jeong, H., Chung, C., van Noije, T., and Takemura, T.: Relationship between fine-mode AOD and precipitation on seasonal and interannual time scales, Tellus B, 66, 23037, doi:10.3402/tellusb.v66.23037, 2014.

Jing, J., Wu, Y., Tao, J., Che, H., Xia, X., Zhang, X., Yan, P., Zhao, D., and Zhang, L.: Observation and analysis of near-surface atmospheric aerosol optical properties in urban Beijing, Particuology, 18, 144-154, 2015.

Jung, J. and Kim, Y.: Tracking sources of severe haze episodes and their physicochemical and hygroscopic properties under Asian continental outflow: Long-range transport pollution, postharvest biomass burning, and Asian dust, J. Geophys. Res., 116, D02206, doi:10.1029/2010JD014555, 2011.

Jung, J., Lee, H., Kim, Y., Liu, X., Zhang, Y., Hu, M., and Sugimoto, N.: Optical Properties of Atmospheric Aerosols Obtained by In-situ and Remote Measurements during 2006 CAREBEIJING Campaign, J. Geophys. Res., 114, D00G02, doi:10.1029/2008JD010337, 2009a.

Jung, J., Lee, H., Kim, Y., Liu, X., Zhang, Y., Gu, J., and Fan, S.: Aerosol chemistry and the effect of aerosol water content on visibility impairment and radiative forcing in Guangzhou during the 2006 Pearl River Delta campaign, J. Environ. Manage., 90, 3231-3244, 2009b.

Jung, J., Kim, Y. J., Lee, K. Y., Cayetano, M. G., Batmunkh, T., Koo, J.-H., and Kim, J.: Spectral optical properties of longrange transport Asian dust and pollution aerosols over Northeast Asia in 2007 and 2008, Atmos. Chem. Phys., 10, 5391-5408, doi:10.5194/acp-10-5391-2010, 2010.
Jung, J., Lee, K., Cayetano, M., Batmunkh, T., and Kim, Y.: Optical and hygroscopic properties of long-range transported haze plumes observed at Deokjeok Island off the west coast of the Korean Peninsula under the Asian continental outflows, J. Geophys, Res., 120, 8861-8877, doi:10.1002/2015JD023154, 2015.

Jung, J., Lyu, Y., Lee, M., Hwang, T., Lee, S., and Oh, S.: Impact of Siberian forest fires on the atmosphere over the Korean Peninsula during summer 2014, Atmos. Chem. Phys., 16, 6757-6770, doi:10.5194/acp-16-6757-2016, 2016.

Kaneyasu, N., Yamamoto, S., Sato, K., Takami, A., Hayashi, M., Hara, K., Kawamoto, K., Okuda, T., and Hatakeyama, S.: Impact of long-range transport of aerosols on the $\mathrm{PM}_{2.5}$ composition at a major metropolitan area in the northern Kyushu area of Japan, Atmos. Environ., 97, 416-425, 2014.

Li, S., Yu, C., Chen, L., Tao, J., Letu, H., Ge, W., Si, Y., and Liu, Y.: Inter-comparison of model-simulated and satellite-retrieved componential aerosol optical depths in China, Atmos. Environ., 141, 320-332, 2016.

Liu, X., Zhang, Y., Jung. J., Gu, J., Li, Y., Guo, S., Chang, S., Yue, D., Lin, P., Kim, Y., Hu, M., Zeng, L., and Zhu, T.: Research on the hygroscopic properties of aerosols by measurement and modeling during CAREBeijing-2006, J. Geophys. Res., 114, D00G16, doi:10.1029/2008JD010805, 2009.

Liu, X. G., Li, J., Qu, Y., Han, T., Hou, L., Gu, J., Chen, C., Yang, Y., Liu, X., Yang, T., Zhang, Y., Tian, H., and Hu, M.: Formation and evolution mechanism of regional haze: a case study in the megacity Beijing, China, Atmos. Chem. Phys., 13, 4501-4514, doi:10.5194/acp-13-4501-2013, 2013.

Mie, G.: Beiträge zur Optik trüber Medien, speziell kolloidaler Metalllüsungen, Ann. Phys., 330, 377-445, doi:10.1002/andp.19083300302, 1908.

Nemesure, S., Wagener, R., and Schwartz, S.: Direct shortwave forcing of climate by the anthropogenic sulfate aerosol: Sensitivity to particle size, composition, and relative humidity, J. Geophys. Res., 100, 26105-26116, 1995.

Park, S., Cho, S., Jo, M., Gong, B., Park, J., and Lee, S.: Field evaluation of a near-real time elemental monitor and identification of element sources observed at an air monitoring supersite in Korea, Atmos Pollut. Res., 5, 119-128, 2014.

Polidori, A., Turpin, B., Lim, H., Cabada, J., Subramanian, R., Pandis, S., and Robinson, A.: Local and Regional Secondary Organic Aerosol: Insights from a Year of Semi-Continuous Carbon Measurements at Pittsburgh, Aerosol Sci. Tech., 40, 861-872, 2006.

Ramanathan, V., Ramana, M., Roberts, G., Kim, D., Corrigan, C., Chung, C., and Winker, D.: Warming trends in Asia amplified by brown cloud solar absorption, Nature, 448, 575-578, doi:10.1038/nature06019, 2007.

Rolph, G.: Real-time Environmental Applications and Display sYstem (READY) Website, available at: http://www.arl.noaa.gov/ ready.php (last access: 2016), NOAA Air Resources Laboratory, Silver Spring, MD, 2016.

Seinfeld, J. and Pandis, S.: Atmospheric Chemistry and Physics: From Air Pollution to Climate Change, John Wiley, Hoboken, N J., 1998.

van Donkelaar, A., Martin, R., Brauer, M., Kahn, R., Levy, R., Verduzco, C., and Villeneuve, P.: Global estimates of ambient fine particulate matter concentrations from satellite-based aerosol optical depth: development and application, Environ. Health Persp., 118, 847-855, 2010. 
Wang, L. T., Wei, Z., Yang, J., Zhang, Y., Zhang, F. F., Su, J., Meng, C. C., and Zhang, Q.: The 2013 severe haze over southern Hebei, China: model evaluation, source apportionment, and policy implications, Atmos. Chem. Phys., 14, 3151-3173, doi:10.5194/acp-14-3151-2014, 2014.

Yue, D. L., Hu, M., Zhang, R. Y., Wang, Z. B., Zheng, J., Wu, Z. J., Wiedensohler, A., He, L. Y., Huang, X. F., and Zhu, T.: The roles of sulfuric acid in new particle formation and growth in the mega-city of Beijing, Atmos. Chem. Phys., 10, 4953-4960, doi:10.5194/acp-10-4953-2010, 2010.
Zhang, R., Li, G., Fan, J., Wu, D., and Molina, M.: Intensification of Pacific storm track linked to Asian pollution, P. Natl. Acad. Sci. USA, 104, 5295-5299, 2007. 